\title{
20. THE PETROGRAPHY, MINERAL CHEMISTRY, AND ONE-ATMOSPHERE PHASE RELATIONS OF BASALTS FROM SITE 395
}

\author{
Michael A. Dungan and Philip E. Long, NRC-Resident Research Associate, \\ NASA Johnson Space Center, Houston, Texas \\ and \\ J. M. Rhodes ${ }^{1}$, Lockheed Electronics Company, Inc., Houston, Texas
}

\begin{abstract}
Two distinct textural-chemical types of basalt are present in Holes 395 and 395A. Aphyric basalts are of two types: those with only olivine on the liquidus and those multiply saturated with plagioclase and olivine. Porphyritic basalts contain phenocrysts of plagioclase, olivine, spinel, and clinopyroxene. There is a discrepancy between the compositions of phenocryst phases in the rocks and olivine and plagioclase produced in one-atmosphere melting experiments. The disequilibrium mineralogy is suggestive of the mixing of primitive and evolved magmas, before eruption, in shallow magma chambers.
\end{abstract}

\section{INTRODUCTION}

We present petrographic descriptions, microprobe data on the compositions of mineral phases, and preliminary experimental results on samples recovered from Site 395 as part of a collaborative characterization of Leg 45 basalts. A companion paper (Rhodes et al., this volume) provides major and trace element analyses of the same suite of samples. Rhodes et al. (this volume) have defined a chemical stratigraphy essentially equivalent to that deduced from shipboard investigations. Two distinct textural-chemical basalt types occur at Site 395.

Four units of basalt lacking macroscopic phenocrysts are referred to as aphyric basalts (Units $A_{1}$ and $A_{2}$, Hole $395 ; \mathbf{A}_{2}, \mathbf{A}_{3}$, and $\mathbf{A}_{4}$, Hole $395 \mathrm{~A}$ ). These basalts do contain microphenocrysts of olivine and plagioclase, and occasional larger crystals that are inferred to be xenocrysts. The aphyric units appear to consist almost entirely of pillow lavas. This is reflected petrographically in fine-grained textures that typically range from glassy or spherulitic in pillow rinds to pillow interiors with intersertal textures. Rare, more coarse-grained basalts with an intersertal-intergranular texture suggest small, local cooling units larger in scale than the average pillow.

The other group of basalts are porphyritic, containing abundant ( 10 to $30 \%$ ) phenocrysts and microphenocrysts of plagioclase, olivine, and clinopyroxene, plus minor spinel microphenocrysts. The porphyritic basalts also occur in both holes as pillowed and massive basalt (Units $\mathrm{P}_{1}$ and $\mathrm{P}_{2}$, Hole 395; Units $\mathrm{P}_{2}, \mathrm{P}_{3}, \mathrm{P}_{4}$, and $\mathrm{P}_{5}$, Hole 395A), and as a sill near the bottom of Hole 395A (Unit $\mathrm{A}_{4}{ }^{\prime}$ ). Consequently, groundmass textures vary from glassy to ophitic.

Rhodes et al. (this volume) have shown that these basalts have very similar trace element signatures (e.g.,

\footnotetext{
${ }^{1}$ Present address: Dept. of Geol. and Geog., Univ. of Massachusetts, Amherst.
}

their chondrite-normalized REE patterns are essentially parallel) indicative of origination from the same source. However, they also have found that simple crystal fractionation of the phenocryst mineralogy is not entirely sufficient to account for chemical differences among or within the various basalt types.

Our purpose is to relate the mineralogy and mineral chemistry of the various flow units to the bulk chemistry of the various units and the crystallization histories of the individual samples. Integration of these data with the results of experimental melting studies of two representative samples from the major basalt types provides some constraints on the fractionation of the units and their interrelationships. Non-equilibrium cooling-rate experiments have been undertaken to determine if basalt textures indicative of variations in cooling history can be produced in the laboratory.

\section{APHYRIC BASALTS}

\section{Petrography}

Petrographically, the aphyric basalts include two subtypes that are most clearly distinguished in the rapidly cooled, spherulitic-textured variants. Basalts of Units $A_{2}$ and $A_{4}$ are characterized by abundant microphenocrysts of olivine. Plate 1, Figures 1-4 illustrates the range of textural variation in Unit $\mathbf{A}_{2}$, corresponding to decreasing cooling rate. The textural relations in Plate 1, Figure 1 indicate crystallization of olivine prior to plagioclase and pyroxene. This interpretation is confirmed by melting relations determined for Sample 395A-9-2, 100-104 cm (see below), which indicate a narrow temperature interval below the liquidus in which olivine crystallizes alone. In contrast, the more evolved basalts of Unit $\mathrm{A}_{3}$ were multiply saturated with olivine and plagioclase at eruption. Evidence for this is found in glassy pillow rinds that contain both phases as microphenocrysts (Plate 1, Figure 8). The presence of plagioclase on the liquidus of these rocks results in a different textural development. Whereas the basalts in $\mathrm{A}_{2}$ and $\mathrm{A}_{4}$ are character- 
ized by radiating fan-spherulites of acicular plagioclase disposed around small glomerophyric aggregates of olivine, the tendency in $\mathrm{A}_{3}$ is for the development of an intersertal texture (Plate 1, Figure 6). These petrographic differences correspond to chemical characteristics. Basalts in Units $\mathrm{A}_{2}$ and $\mathrm{A}_{4}$ are less evolved (normative olivine $=9.4$ to $12.0 \%$ ) than those in $\mathrm{A}_{3}$ (normative olivine $=5.9$ to $9.6 \%$ )

We have analyzed the compositions of plagioclase and olivine (Tables 1 and 2) in six and eight of the aphyric basalts, respectively. The range of olivine microphenocryst compositions in rapidly cooled rocks is quite narrow at $\mathrm{Fo}_{85-82}$. This corresponds to the liquidus olivine in the experimental study of Sample $395 \mathrm{~A}-9-2,100-104 \mathrm{~cm}$, which is $\mathrm{Fo}_{83}$. Olivine in the intergranular basalt Sample 395A-64, CC is zoned from $\mathrm{Fo}_{85}$ to $\mathrm{Fo}_{75}$. Laths and needles of plagioclase in rapidly cooled rocks are similarly restricted in composition $\left(\mathrm{An}_{66-59}\right)$, and are also comparable to the experimentally produced plagioclase $\left(\mathrm{An}_{62}\right)$.

Included within the basalts of Unit $\mathrm{A}_{3}$ are rare large crystals of olivine and plagioclase. A large anhedral grain in Sample 395A-41-1, 107-111 cm is considerably more magnesian $\left(\mathrm{Fo}_{88}\right)$ than the associated microphenocrysts. A euhedral olivine grain that also includes a grain of chromite, in Sample 395A-60-1, 66$70 \mathrm{~cm}$, is also anomalously magnesian $\left(\mathrm{Fo}_{87}\right)$. Similarly, a plagioclase grain attached to the anhedral olivine grain in the Core 41 sample is $\mathrm{An}_{86-79}$, and the large anhedral grain figured in Plate 1, Figures 7 and 8 (Sample 395A-56-3, 63-65 cm) is also more calcic $\left(\mathrm{An}_{83-79}\right)$ than the microphenocrysts. On the basis of their more primitive compositions and the typical anhedral and embayed morphologies of these crystals, they are xenocrysts rather than phenocrysts.

\section{PORPHYRITIC BASALTS}

\section{Petrography}

The porphyritic basalts recovered at Site 395 have clearly had, at minimum, two-stage cooling histories, in that glassy pillow rinds contain large equant phenocrysts and microphenocrysts. Whereas most porphyritic ocean-floor basalts contain olivine and plagioclase phenocrysts ( \pm spinel) on eruption, the porphyritic basalts at Site 395 are triply saturated with the silicate phases plagioclase, olivine, and clinopyroxene. An important characteristic of this phenocryst assemblage, from the petrographic standpoint, is that there is a diversity of crystal morphologies, types of glomerophyric intergrowths, and zoning patterns. Additional phases that crystallize at near-liquidus temperatures are sulfide and chromite. That sulfide is an early crystallizing phase is demonstrated by its inclusion in both plagioclase and spinel. Spinel occurs within plagioclase and olivine and in the groundmass, but is never

TABLE 1

Microprobe Analyses of Plagioclase

\begin{tabular}{|c|c|c|c|}
\hline Unit & $\begin{array}{l}\text { Sample } \\
\text { (Interval in cm) }\end{array}$ & Anorthite-Content & Petrography \\
\hline \multicolumn{4}{|c|}{ Aphyric Basalts } \\
\hline $\mathrm{A}_{2}$ & $395-11-2,100-105$ & $59-61$ & Groundmass needles \\
\hline $\mathrm{A}_{2}$ & $295-16-3,3-8$ & & \\
\hline \multirow[t]{2}{*}{$\mathrm{A}_{3}$} & $395 \mathrm{~A}-41-1,107-111$ & $86-79$ & Rounded xenocryst in spherulitic groundmass, irregular zoning pattern \\
\hline & $395 \mathrm{~A}-41-1,107-111$ & $64-62$ & Groundmass needles \\
\hline \multirow[t]{2}{*}{$\mathrm{A}_{3}$} & $395 \mathrm{~A}-56-3,62-65$ & $83-79$ & Rounded xenocryst in glass rind with spherulitic overgrowth \\
\hline & $395 \mathrm{~A}-56-3,62-65$ & $65-63$ & Groundmass needles and in glass \\
\hline $\mathrm{A}_{4}$ & $395 \mathrm{~A}-64, \mathrm{CC}$ & $68-43$ & Core-to-rim zoning in laths in intersertal-intergranular basalt \\
\hline A4 & $395 \mathrm{~A}-67, \mathrm{CC}$ & $66-64$ & Groundmass needles \\
\hline \multicolumn{4}{|c|}{ Porphyritic Basalts } \\
\hline \multirow[t]{4}{*}{$\mathrm{P}_{2}$} & $395 \mathrm{~A}-15-5,16-20$ & $86-83$ & Core of large equant phenocrysts ( 5 grains) \\
\hline & (coarse-grained & $81-78$ & Core compositions in phenocryst ( 1 grain) \\
\hline & groundmass) & $73-71$ & Most calcic composition of rims on large phenocrysts \\
\hline & & $73-24(0 r=0.6-1.1)$ & Range of rim compositions on large phenocrysts \\
\hline \multirow[t]{2}{*}{$\mathrm{P}_{3}$} & $395 \mathrm{~A}-17-1,46-55$ & $84-83$ & Core of large equant phenocryst \\
\hline & & $71-62$ & $\begin{array}{l}\text { Most calcic composition and most sodic compositions from interior to edge of rim } \\
\text { on the same phenocryst. Normal zoning with very weak oscillatory zoning }\end{array}$ \\
\hline \multirow[t]{7}{*}{$\mathrm{P}_{4}$} & $395 \mathrm{~A}-27-2,111-116$ & $83-85$ & Reverse zoned core of large equant grain intergrown with olivine in glomerocryst \\
\hline & $\begin{array}{l}\text { (fine-grained } \\
\text { groundmass) }\end{array}$ & $73-63$ & $\begin{array}{l}\text { Most calcic and sodic compositions (interior to edge) within rim on the same } \\
\text { phenocryst }\end{array}$ \\
\hline & & $85-79$ & Range of compositions within oscillatory zone d, large equant phenocryst \\
\hline & & $72-63$ & Range of rim compositions on same phenocryst \\
\hline & & 83 & Core of oscillatory zoned microphenocryst \\
\hline & & 86 & Rim of core portion of the same grain \\
\hline & & $73-71$ & Interior of the rim of the same grain \\
\hline \multirow[t]{5}{*}{$\mathrm{P}_{5}$} & $395 \mathrm{~A}-28-1,116-120$ & $85-77$ & $\begin{array}{l}\text { Range of compositions within oscillatory zoned core of large equant phenocryst in } \\
\text { glass }\end{array}$ \\
\hline & & $72-70$ & Range of the rim composition on the same grain (in glass) \\
\hline & & $84-69$ & Range of compositions in small laths of plagioclase (in glass) \\
\hline & & $59-60$ & Core of exotic, partly resorbed grain \\
\hline & & $69-71$ & Rim overgrowth on same grain \\
\hline
\end{tabular}


TABLE 2

Microprobe Analyses of Olivine

\begin{tabular}{|c|c|c|c|}
\hline Unit & $\begin{array}{c}\text { Sample } \\
\text { (Interval in } \mathrm{cm} \text { ) }\end{array}$ & Forsterite Content & Petrography \\
\hline $\mathrm{A}_{1}$ & $395-11-1,136-138$ & 84.3 & Skeletal microphenocryst \\
\hline \multirow[t]{2}{*}{$\mathrm{A}_{2}$} & $395-11-2,100-105$ & $83.9-83.8$ & Core of microphenocryst \\
\hline & & 82.1 & Rim of same grain \\
\hline $\mathrm{A}_{2}$ & $395-16-3,3-8$ & $84.1-83.8$ & Skeletal microphenocrysts \\
\hline $\mathrm{A}_{3}$ & $395 \mathrm{~A}-41-1,107-111$ & $\begin{array}{l}88.4 \\
84.4\end{array}$ & Core of large anhedral xenocryst \\
\hline $\mathrm{A}_{3}$ & $395 \mathrm{~A}-56-3,62-65$ & $\begin{array}{l}84.4 \\
83.7\end{array}$ & $\begin{array}{l}\text { Kim or same grain } \\
\text { Microphenocryst in glass }\end{array}$ \\
\hline \multirow[t]{3}{*}{$\mathrm{A}_{4}$} & $395 \mathrm{~A}-60-1,66-70$ & 87.0 & Core of euhedral phenocryst containing chromite inclusion \\
\hline & & 85.3 & Rim of same grain \\
\hline & & 83.8 & Groundmass \\
\hline \multirow[t]{2}{*}{$\mathrm{A}_{4}$} & $395 \mathrm{~A}-64, \mathrm{CC}$ & 82.5 & Core of granular olivine in intergranular-intersertal basalt \\
\hline & & 75.4 & Rim of a granular olivine \\
\hline$A_{5}$ & $395 \mathrm{~A}-67, \mathrm{CC}$ & $85.1-84.0$ & Skeletal microphenocrysts and groundmass \\
\hline \multirow[t]{3}{*}{$\mathrm{P}_{1}$} & $395-18-2,43-46$ & $85.6-85.4$ & Cores of microphenocrysts (2) \\
\hline & & 84.8 & Rim of a microphenocryst \\
\hline & & 87.0 & Core of large phenocryst in glomerophyric aggregate \\
\hline \multirow[t]{3}{*}{$\mathrm{P}_{2}$} & $395 \mathrm{~A}-15-4,10-15$ & $88.0-85.6$ & Cores of large phenocrysts (3) \\
\hline & & $81.9-81.3$ & Cores of microphenocrysts (3) \\
\hline & & $75-58$ & Rims of microphenocrysts (3) \\
\hline \multirow[t]{4}{*}{$\mathrm{P}_{2}$} & $395 \mathrm{~A}-15-5,16-20$ & $87.7-87.5$ & Cores of large phenocrysts (2), one of which contains a spinel inclusion \\
\hline & & 85.7 & Core of large euhedral phenocryst \\
\hline & & $83.4-81.2$ & Cores of small grains (3) \\
\hline & & $77-61$ & Rims of groundmass grains \\
\hline \multirow[t]{2}{*}{$\mathrm{P}_{3}$} & $395 \mathrm{~A}-17-1,46-55$ & 87.8 & Core of large phenocryst \\
\hline & & $85.5-85.0$ & Cores and rims of microphenocrysts ( 3 ) in glass \\
\hline \multirow[t]{2}{*}{$\mathrm{P}_{3}$} & $395 \mathrm{~A}-19-1,132-136$ & 89.2 & Core of large euhedral phenocryst \\
\hline & & 87.5 & Core of large euhedral phenocryst \\
\hline \multirow[t]{2}{*}{$\mathrm{P}_{4}$} & $395 \mathrm{~A}-26-2,125-129$ & $87.4-85.3$ & Cores of variable-sized phenocrysts (4) \\
\hline & & 84.6 & Rim of microphenocryst in glass \\
\hline \multirow[t]{3}{*}{$\mathrm{P}_{4}$} & $395 \mathrm{~A}-27-2,111-116$ & $89.0-86.3$ & Cores of large phenocrysts anhedral and euhedral (5) \\
\hline & & $84.8-84.2$ & Cores of microphenocrysts (3) \\
\hline & & 82.5 & Rim of a microphenocryst \\
\hline \multirow[t]{2}{*}{$\mathrm{P}_{5}$} & $395 \mathrm{~A}-28-1,116-122$ & 87.9 & Phenocryst cores (2) \\
\hline & & $84.8-84.3$ & Microphenocryst cores and rims in glass (5) \\
\hline
\end{tabular}

intergrown with clinopyroxene phenocrysts. These relations are consistent with one-atmosphere phase relations determined for one of the porphyritic basalts (see below). The petrography and chemistry of the four phenocryst phases plagioclase, olivine, spinel, and clinopyroxene are discussed separately in order of crystallization sequence.

\section{Plagioclase}

Plagioclase is the most abundant and most coarsegrained phenocryst phase in the Site 395 porphyritic basalts. We do not have quantitative modal data, but a visual estimate for glassy basalts suggests approximately 10 to 20 per cent plagioclase phenocrysts. Plagioclase phenocrysts range in size from large equant grains up to $5 \mathrm{~mm}$ in diameter to lath-shaped microphenocrysts less than $0.1 \mathrm{~mm}$. In general, as the size of the phenocrysts decreases they become less equant and increasingly elongate. Of the four phenocryst phases present, plagioclase exhibits the most diversity in morphology and zoning patterns. Several distinct types of zoning patterns have been recognized, and examples of some of these have been studied in reconnaissance with the microprobe. We have performed three element analyses $(\mathrm{Ca}-\mathrm{K}-\mathrm{Na})$ that are corrected for deadtime, drift, and background, and converted directly to end-member feldspar ternary component.

Plagioclase phenocrysts in phyric Units $\mathrm{P}_{1}$ and $\mathrm{P}_{2}$ (Hole 395, Cores 18 and 19; Hole 395A, Cores 13 through 15, Section 4) are comprised of large equant grains (about 3 to $5 \mathrm{~mm}$ ) and laths (Plate 2, Figure 1). Glomerophyric aggregates of plagioclase are common. Although these plagioclases contain chromite inclusions, olivine and clinopyroxene are not typically intergrown with plagioclase glomerocrysts in this unit. The cores of these phenocrysts are distinctive in that the majority of them are very weakly zoned. A weak normal gradient is present near the margin of the core, and irregular patches of a slightly more sodic composition occur around concentrations of small melt inclusions (about 5 to $10 \mu \mathrm{m}$ ). However, the typical compositional range of these cores is $\mathrm{An}_{86-83}$. The boundary between the cores and rim overgrowths is generally a sharp optical discontinuity which corresponds to a compositional gap or an extremely narrow zone with a very high gradient. The most calcic rim composition recorded for these phenocrysts is $\mathrm{An}_{73}$, indicating a possible hiatus of 10 mole per cent An. The rims are normally zoned with narrow (about 1 to $2 \mu \mathrm{m}$ ) oscillatory zones superim- 
posed. The extent of zoning varies from narrow rims on phenocrysts in glass $\left(\mathrm{An}_{73-63}\right)$ to much larger rims on phenocrysts in coarse-grained rocks. The compositional relations in lath plagioclase in these rocks warrant further investigation.

The majority of large plagioclase phenocrysts in the stratigraphically lower porphyritic basalts (Core 15, Section 5 through Core 33 and Cores 61 through 64, Section 1) exhibit similar zoning patterns, characterized by large equant cores and sharply zoned, more sodic rims. However, the cores have much better developed oscillatory zoning and an apparently larger compositional range $\left(\mathrm{An}_{85-77}\right)$, although more data are needed before rigorous comparisons.

Two additional distinctive petrographic types are present in subordinate amounts. These differ from the equant grains discussed above in that they are riddled with elongate melt inclusions. The more abundant of the two types occurs as large equant grains ( 3 to 5 $\mathrm{mm}$ ) containing numerous regularly spaced cavities elongate in the direction of (010). Concentric normal zoning is developed around the melt inclusions. The core-rim boundaries are highly irregular (Plate 2, Figure 2). We interpret these features as evidence of resorption, followed by reprecipitation. We have not analyzed these grains with the microprobe. The second type of inclusion-filled feldspars occurs as laths rather than equant grains, and consists of a core rimmed by an irregular vermicular zone, which is in turn mantled by an inclusion-free rim (Plate 2, Figure 3 ). One grain of this type has been analyzed and was found to have a sodic core $\left(A n_{60-59}\right)$ with a more calcic rim $\left(A n_{71-69}\right)$.

It must be emphasized that this preliminary and generalized characterization of the plagioclase phenocrysts by no means describes all the textural and compositional variation in plagioclase of these rocks. However, these fragmentary data do establish the presence of several feldspar populations in porphyritic basalts at Site 395 that have had different crystallization histories. A comparison of compositions of the phenocrysts with the one-atmosphere liquidus plagioclase in Sample 395A-27-2, 111-116 cm shows a large discrepancy. Specifically, the phenocrysts are considerably more anorthite-rich than the experimental plagioclase $\left(\mathrm{An}_{86}\right.$ vs. $\left.\mathrm{An}_{74}\right)$. Thus, the composition of the liquidus plagioclase (in the experimental run) falls within the hiatus between the large phenocryst cores and the more sodic rims.

\section{Spinel}

With a single exception, spinel grains larger than 10 $\mu \mathrm{m}$ in basalts at Site 395 are restricted to the phyric basalts. The spinels occur as inclusions in plagioclase and olivine phenocrysts (never clinopyroxene) and in the groundmass. Spinels included in olivine and plagioclase are subhedral to anhedral, whereas those in the groundmass are generally euhedral with sharp idiomorphic outlines. The latter typically contains melt inclusions. One grain of spinel included within a large melt inclusion in plagioclase in Sample 395A-13-1,
$142-147 \mathrm{~cm}$ is an irregular, web-shaped grain, distinct in composition from the general population.

We have analyzed spinels in 14 thin sections from Hole 395A. Most of the sections contain only two or three grains, commonly as inclusions in the same plagioclase phenocryst. Groundmass spinel is rare compared with inclusions. The data are presented on Figure 1 in terms of $\mathrm{Cr} /(\mathrm{Cr}+\mathrm{Al})$ versus $\mathrm{Mg}$ / $(\mathrm{Mg}+\mathrm{Fe})$, and permit several generalizations concerning composition versus distribution. The spinels in the more evolved phyric Unit $\mathrm{P}_{2}$ plot with consistently low $\mathrm{Cr} /(\mathrm{Cr}+\mathrm{Al})$, compared with those in $\mathrm{P}_{3}, \mathrm{P}_{4}$, and $\mathrm{P}_{5}$. They also exhibit a somewhat wider range in $\mathrm{Mg}$ / $(\mathrm{Mg}+\mathrm{Fe})$. The only analyzed groundmass spinel in $\mathrm{P}_{2}$ is the aforementioned anomalous web-shaped grain. Note that it has considerably higher $\mathrm{Cr} /(\mathrm{Cr}+\mathrm{Al})$ than the grains included in plagioclase or olivine. Within Units $\mathrm{P}_{3}, \mathrm{P}_{4}$, and $\mathrm{P}_{5}$ there is also a tendency for lower $\mathrm{Cr} /(\mathrm{Cr}+\mathrm{Al})$ in spinels that are included in other phenocrysts, as opposed to groundmass spinel. A single grain of spinel is included in an olivine microphenocryst in the very sparsely phyric Unit $\mathrm{A}_{3}$ (Sample 395A-60-1, 66-70 cm).

Zoning trends in spinel were investigated by analyzing the cores and rims of several grains. Three zoning trends were recognized. Most of the spinel in contact with the groundmass is zoned to higher $\mathrm{Cr} /(\mathrm{Cr}+\mathrm{Al})$, with slightly decreasing $\mathrm{Mg} /(\mathrm{Mg}+\mathrm{Fe})$. This trend mimics the overall trend of $\mathrm{Cr}$-enrichment from inclusions to groundmass spinel. Some groundmass spinel grains have narrow rims zoned toward titanomagnetite. Microprobe analyses at the grain boundaries are characterized by higher $\mathrm{TiO}_{2}$, lower $\mathrm{Mg} /(\mathrm{Mg}+\mathrm{Fe})$, and little change in $\mathrm{Cr} / \mathrm{Al}$. A third trend results from reequilibration between spinel and plagioclase. In these grains, $\mathrm{Cr} /(\mathrm{Cr}+\mathrm{Al})$ decreases with increasing $\mathrm{Mg} /$ $(\mathrm{Mg}+\mathrm{Fe})$. Three spinel grains produced in experimental runs with Sample 395A-27-2, 111-116 cm at $1200^{\circ} \mathrm{C}$ are plotted in Figure 1 and listed in Table 3. They have compositions quite similar to the natural spinels.

The compositional range defined by the Hole $395 \mathrm{~A}$ spinels is essentially the same as that encompassed by spinels in oceanic tholeiites of a similar composition (Sigurdsson and Schilling, 1976; Dick, in press). The aluminous spinels characteristic of the highly magnesian primitive tholeiites found on Legs 2, 3, 37, and in the FAMOUS area (Frey et al., 1974; Sigurdsson and Schilling, 1976; Dick, in press,) have not been found.

\section{Olivine}

The Site 395 porphyritic basalts contain approximately 5 to 10 per cent olivine phenocrysts and microphenocrysts. As with the plagioclase phenocrysts, a variety of morphologies is present. In addition to the typical euhedral to subhedral, equant phenocrysts and microphenocrysts ( 3.0 to $0.1 \mathrm{~mm}$ ), there are anhedral grains including some that are highly irregular. These tend to be ameboid, and in some cases are intergrown with plagioclase laths or equant grains as glomero- 


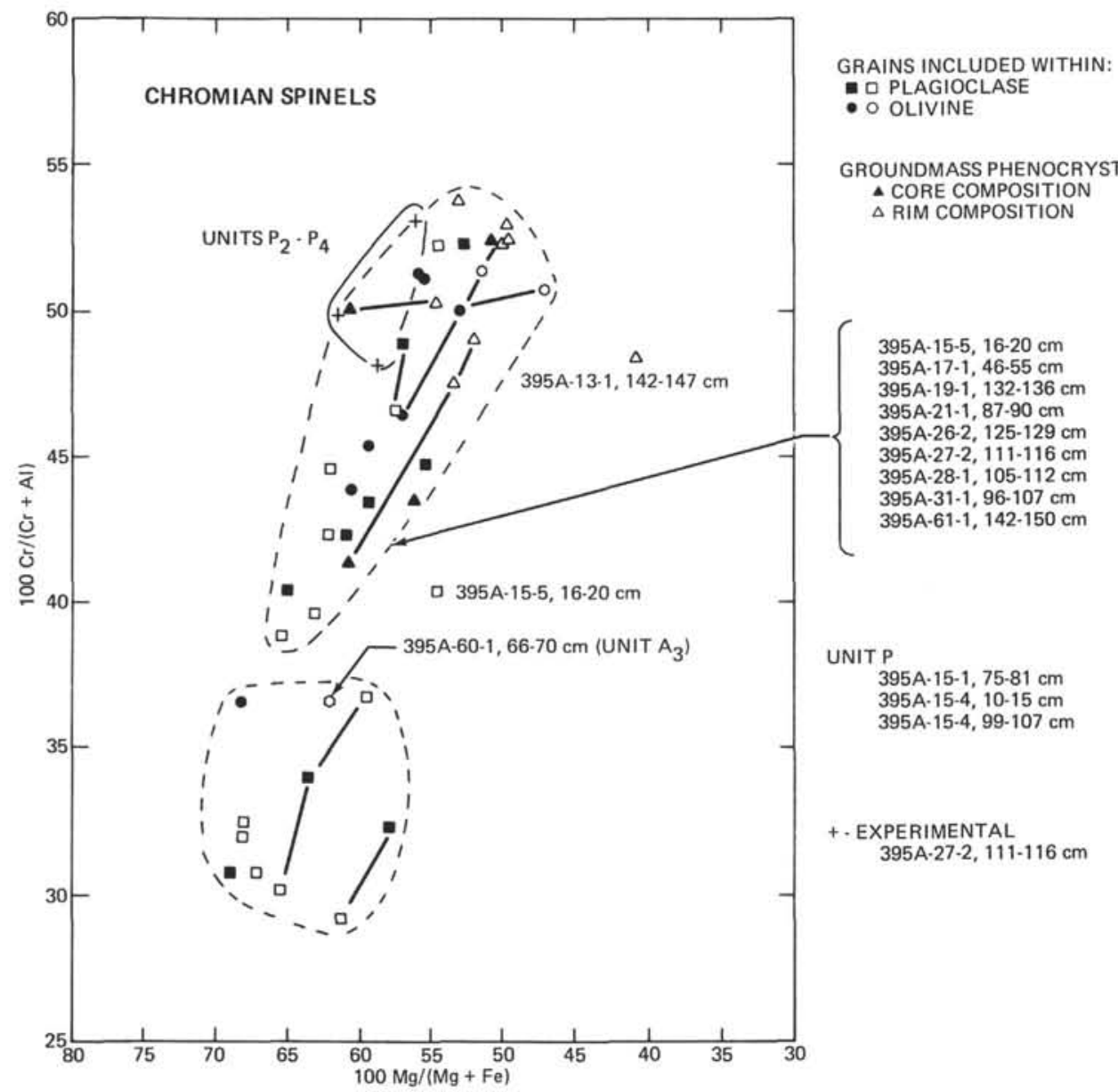

Figure 1. Microprobe analyses of spinels in porphyritic basalts (Hole 395A). The presence of melt inclusions in many spinel grains indicates that they are products of basalt crystallization. Many of the grains are included within olivine and plagioclase, and the compositions reflect, in part, re-equilibration with host grain and crystallization from trapped liquid. Zoning in groundmass grains shows two trends: one exhibits simple $\mathrm{CrFe}$ enrichment, and the other shows FeTi enrichment at relatively constant Cr/Al.

crysts. This texture suggests resorption at some stage in the crystallization of the olivine. Skeletal olivine microphenocrysts are present in some rocks, where they are typically intergrown with highly elongate plagioclase laths.

The results of olivine analyses in eight porphyritic basalts are presented in Table 2. The olivine phenocryst compositions range from $\mathrm{Fo}_{89}$ to $\mathrm{Fo}_{85}$. Microphenocrysts and the rims of grains in glass or in rapidly quenched groundmass are $\mathrm{Fo}_{85-82}$; the majority are at $\mathrm{Fo}_{84}$. As in the aphyric basalts, iron enrichment in the olivine with more slowly cooled groundmasses increases over the amount found in glassy rocks. The maximum Fo content of phenocrysts in these rocks correlates weakly with the $\mathrm{Mg}^{1}$ of the bulk rock. For samples with $\mathrm{Mg} /\left(\mathrm{Mg}+\mathrm{Fe}^{*}\right)=0.59$ to 0.64 , the most magnesian olivines are $\mathrm{Fo}_{87-88}$, whereas $\mathrm{Fo}_{89}$ olivines have been recorded in basalts with $\mathrm{Mg}^{\prime}=0.64$ to 0.67 .

${ }^{1} \mathrm{Mg}^{\prime}=\mathrm{Mg} /\left(\mathrm{Mg}+\mathrm{Fe}^{*}\right)=\mathrm{Fe}_{\text {total }} \times 0.9$
However, these olivines are substantially more magnesian than the olivine recorded in the one-atmosphere experimental study of Sample 395A-27-2, 111-116 cm $\left(\mathrm{Fo}_{85}\right)$. They are also more magnesian than the values predicted by a $\mathrm{K}_{\mathrm{D}}$ of 0.28 , as determined by Roeder and Emslie (1970). Thus, there is, between the natural and experimental olivine compositions, a discrepancy analogous to that recognized for plagioclase.

\section{Clinopyroxene}

Many of the porphyritic basalts contained clinopyroxene phenocrysts on eruption. Large crystals (i.e., $>3 \mathrm{~mm}$ ) are rare, and in general clinopyroxene phenocrysts range in size from 0.2 to $1.0 \mathrm{~mm}$ and are smaller than the large associated olivine and plagioclase phenocrysts. Although plagioclase and olivine phenocrysts are abundant (15 to 20\%) in all the porphyritic basalts, the distribution of clinopyroxene phenocrysts is more variable, in that they are altogether absent from some of the thin sections examined. 
TABLE 3

Microprobe Analyses of Spinels, Leg 45

\begin{tabular}{|c|c|c|c|c|c|c|c|c|c|c|}
\hline & 1 & 2 & 3 & 4 & 5 & 6 & 7 & 8 & 9 & 10 \\
\hline $\mathrm{TiO}_{2}$ & 2.1 & 0.53 & 0.43 & 0.92 & 0.55 & 0.72 & 0.41 & 0.47 & 0.65 & 0.40 \\
\hline $\mathrm{Al}_{2} \mathrm{O}_{3}$ & 22.7 & 36.5 & 38.9 & 33.0 & 31.0 & 25.9 & 32.2 & 26.2 & 24.8 & 26.6 \\
\hline $\mathrm{Cr}_{2} \mathrm{O}_{3}$ & 31.4 & 26.8 & 25.2 & 28.7 & 32.6 & 35.1 & 32.9 & 39.0 & 37.6 & 38.3 \\
\hline $\mathrm{Fe}_{2} \mathrm{O}_{3} *$ & 12.6 & 6.4 & 5.3 & 6.3 & 6.7 & 8.9 & 5.6 & 5.5 & 7.8 & - \\
\hline $\mathrm{FeO}$ & 19.6 & 11.8 & 11.3 & 13.3 & 12.5 & 14.3 & 11.6 & 12.9 & 14.3 & 16.9 \\
\hline $\mathrm{MnO}$ & 0.31 & 0.18 & 0.17 & 0.24 & 0.23 & 0.28 & 0.18 & 0.27 & 0.28 & 0.24 \\
\hline $\mathrm{MgO}$ & 11.4 & 17.0 & 17.4 & 15.6 & 16.0 & 14.4 & 16.9 & 15.2 & 14.2 & 15.1 \\
\hline Total & 100.1 & 99.2 & 98.7 & 98.1 & 99.6 & 99.6 & 99.4 & 99.5 & 99.6 & 97.5 \\
\hline FeO Total & 30.9 & 17.5 & 16.1 & 18.9 & 18.5 & 22.3 & 16.2 & 17.8 & 21.4 & 16.9 \\
\hline \multicolumn{11}{|c|}{ Cations Calculated on the Basis of 32 Oxygens } \\
\hline $\mathrm{Ti}$ & 0.403 & 0.093 & 0.075 & 0.166 & 0.099 & 0.135 & 0.073 & 0.086 & 0.122 & 0.075 \\
\hline Al & 6.929 & 10.033 & 10.568 & 9.358 & 8.739 & 7.587 & 8.968 & 7.542 & 7.269 & 7.726 \\
\hline $\mathrm{Cr}$ & 6.427 & 4.940 & 4.591 & 5.458 & 6.163 & 6.895 & 6.144 & 7.528 & 7.390 & 7.452 \\
\hline $\mathrm{Fe}^{+3}$ & 2.359 & 1.103 & 0.909 & 1.115 & 1.178 & 1.622 & 0.975 & 0.994 & 1.432 & - \\
\hline $\mathrm{Fe}^{+2}$ & 4.086 & 2.251 & 2.150 & 2.621 & 2.454 & 2.894 & 2.177 & 2.585 & 2.918 & 3.486 \\
\hline Mn & 0.068 & 0.036 & 0.033 & 0.049 & 0.047 & 0.059 & 0.036 & 0.056 & 0.059 & 0.051 \\
\hline $\mathrm{Mg}$ & 4.399 & 5.907 & 4.976 & 5.592 & 5.702 & 5.314 & 5.950 & 5.531 & 5.261 & 5.547 \\
\hline Total & 24.671 & 24.421 & 24.346 & 24.426 & 24.450 & 24.624 & 24.371 & 24.379 & 24.549 & 24.336 \\
\hline $\mathrm{Cr} /(\mathrm{Cr}+\mathrm{A} 1)$ & 0.481 & 0.330 & 0.303 & 0.368 & 0.414 & 0.476 & 0.407 & 0.500 & 0.504 & 0.491 \\
\hline $\mathrm{Mg} /(\mathrm{Mg}+\mathrm{Fe})$ & 0.397 & 0.634 & 0.658 & 0.595 & 0.606 & 0.534 & 0.650 & 0.603 & 0.542 & 0.641 \\
\hline
\end{tabular}

Note: $\mathrm{Fe}_{2} \mathrm{O}_{3} *$ calculated on the assumption of stoichiometry. (1) $395 \mathrm{~A}-13-1,142-147 \mathrm{~cm}$ : Unusual web-shaped grain which occurs in a large crystalline melt inclusion within a plagioclase phenocrysts (Unit $\left.P_{1}\right) ;(2,3,4) 395$ 15-4, 10-15 cm: Core and opposite rims of a spinel grain included within plagioclase. \#3 is the composition of the rim facing the interior of the plagioclase, \#4 is located at the rim of the plagioclase (Unit $\left.P_{1}\right) ;(5,6) 395 \mathrm{~A}$ 27-2, 111-116 cm: Core and rim of a euhedral octahedron of spinel included within a fine-grained ground mass (Unit $\mathrm{P}_{3}$ ); (7) $395 \mathrm{~A}-27-2,111-116 \mathrm{~cm}$ : Core of subhedral spinel included along a plagioclase-olivine grain boundary in a glomerocrystic aggregate $\left(\right.$ Unit $\left.\mathrm{P}_{3}\right) ;(8,9) 395 \mathrm{~A}-21-1,87-90 \mathrm{~cm}$ : Core and rim of a euhedral grain included within fine-grained ground mass (Unit $\mathrm{P}_{2}$ ); (10) Experimentally produced spinel in $1200^{\circ} \mathrm{C}$ melting run using powder of Sample $395 \mathrm{~A}-27-2,111-116 \mathrm{~cm} . \mathrm{p}=1$ atmosphere, $\mathrm{f}_{\mathrm{o}_{2}}=10^{-9}$.

The presence or absence of clinopyroxene phenocrysts does not appear to be correlated with bulk chemistry, since they are present in all five of the chemically defined porphyritic units, and chemical differences among these units are not large in any case.

The clinopyroxene phenocrysts occur attached to plagioclase laths in glomerocrystic aggregates or intergrown in the characteristic bow-tie texture interpreted as evidence of co-precipitation (Bryan, 1972). Most of the grains are euhedral, or where complex intergrowths have formed, subhedral. Irregular extinction, a common feature in ocean-floor basalt pyroxene phenocrysts (Bryan, 1972) and complex zoning patterns (sector zoning and concentric oscillatory zoning superimposed on normal zoning), are present (Plate 2, Figure 6).

\section{Pyroxene Chemistry}

The chemical compositions of phenocrysts and groundmass clinopyroxene in five porphyritic basalts have been investigated in reconnaissance with the electron microprobe (Figures 2, 3, and 4; Table 4). Spot analyses were taken along linear traverses from core to rim or from rim to rim, in order to characterize the gross zoning trends and the chemical differences between phenocryst and groundmass grains. As noted previously by Bence et al. (1976) in a study of pyroxene phyric basalts from Leg 15, the distinction between phenocrysts and groundmass pyroxenes is best made on the basis of chromium content. Analyses of large phenocrysts in fine-grained matrices indicate, from core to rim, a very slight iron enrichment and calcium depletion trend typical of ocean-floor basalt clinopyroxene phenocrysts (e.g., $\mathrm{Wo}_{44} \mathrm{En}_{48} \mathrm{Fs}_{7}$ to $\mathrm{Wo}_{40} \mathrm{En}_{48}$ $\mathrm{Fs}_{12}$ ). Over this interval, however, the typical chromium content of the core ( 1.5 to $1.1 \mathrm{wt} \% \mathrm{Cr}_{2} \mathrm{O}_{3}$ ) is decreased by a factor of $1 / 2$ to $1 / 3$ at the rim; alumina undergoes a similar depletion from 3.5-4.5 per cent $\mathrm{Al}_{2} \mathrm{O}_{3}$ to 1.5-3.0 weight per cent, and in general titania increases, although the trend is diffuse and subject to oscillations. In rocks that contain abundant groundmass pyroxene, the outer rims of the phenocrysts are strongly depleted in $\mathrm{Cr}_{2} \mathrm{O}_{3}(<0.10 \mathrm{wt} \%)$, relative to their cores, even though the relative iron enrichment is still meager (e.g., $\mathrm{Wo}_{40} \mathrm{En}_{44} \mathrm{Fs}_{16}$ ). The marked tendency for $\mathrm{Cr}$ depletion with progressive crystallization is illustrated in Figure 3. The strong partitioning of chromium into clinopyroxene, relative to liquid, explains the sharp depletion trend within single grains; once closed-system crystallization ensues (i.e., subsequent to eruption), clinopyroxene crystallization rapidly depletes residual liquid in chromium.

The chemical zoning in groundmass grains also exhibits iron and titanium enrichment, accompanied by decreases in calcium, aluminum, and chromium. Some of the larger groundmass grains are cored by relatively high-chromium compositions, indicating that the very marked decrease in $\mathrm{Cr}$ characteristic of phenocryst rims and groundmass grains was caused by early growth of abundant grains formed near the surface or after eruption, and not entirely by a few large phenocrysts formed at depth. The iron enrichment trend recorded in groundmass pyroxenes is typical of ocean-floor 


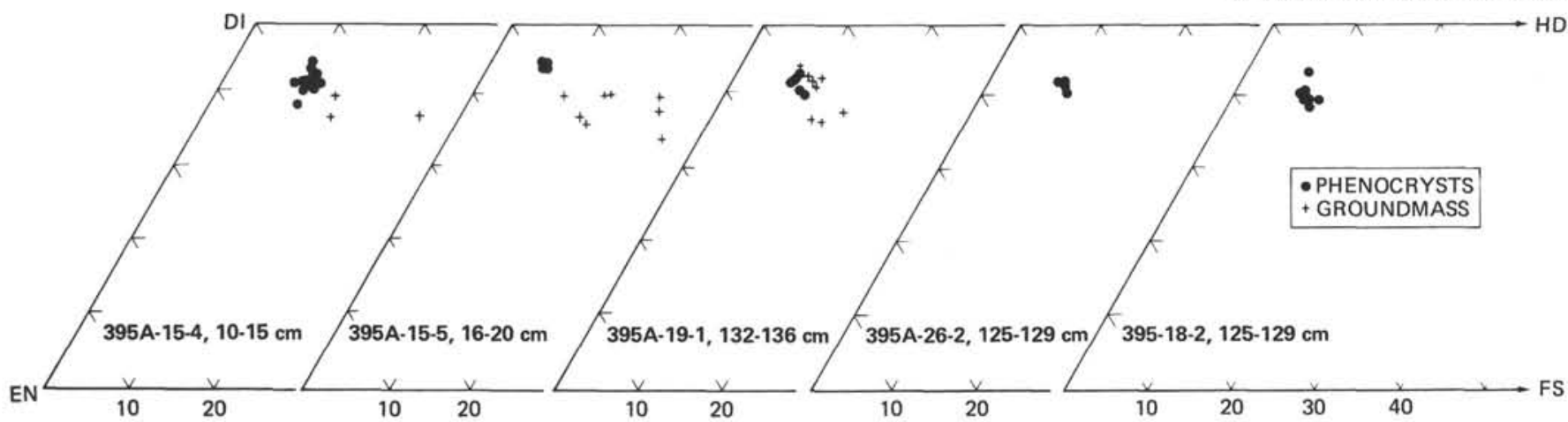

Figure 2. Pyroxenes from five porphyritic basalts, Holes 395 and $395 \mathrm{~A}$.

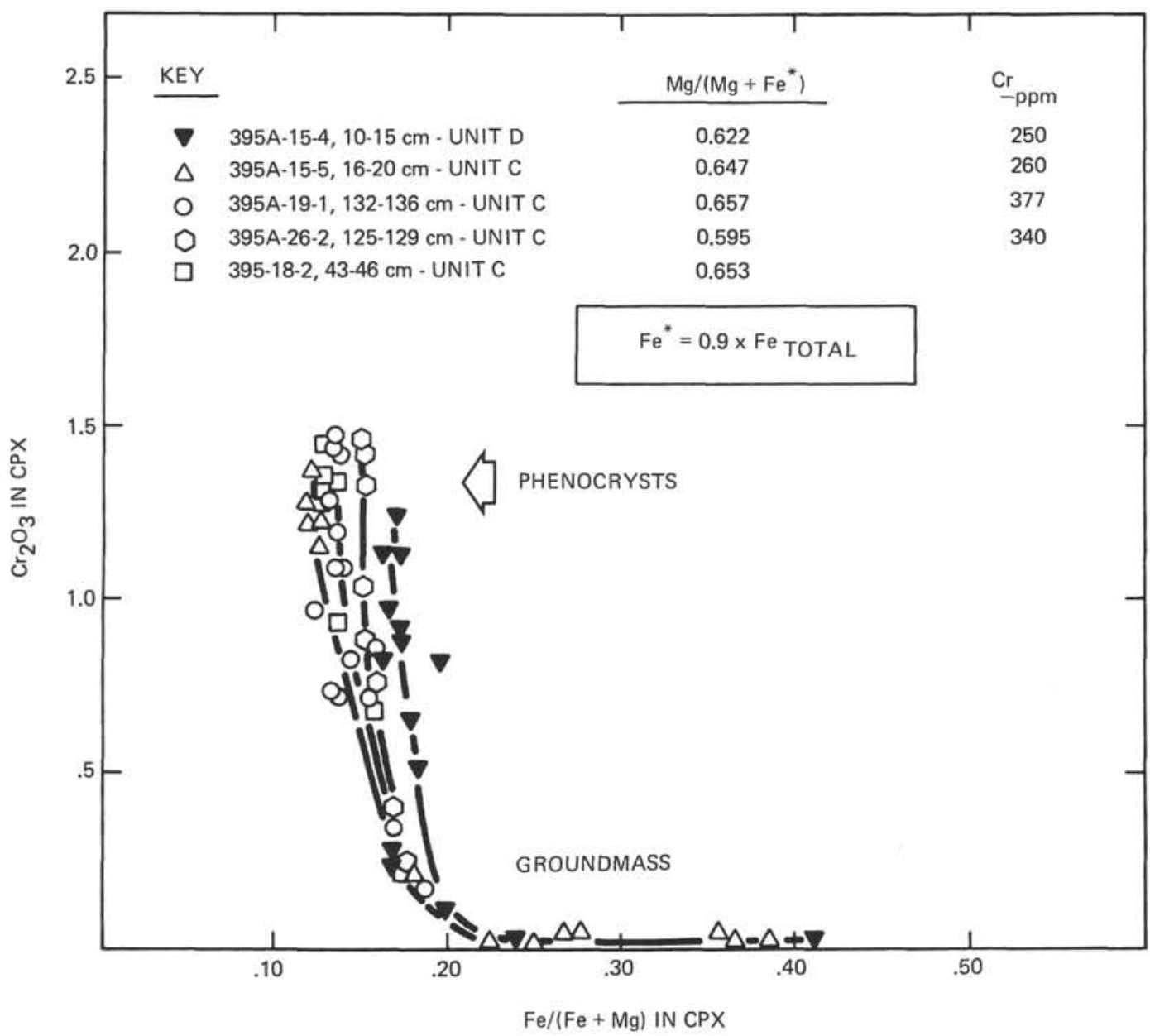

Figure 3. Microprobe analyses of clinopyroxene phenocrysts and groundmass pyroxene in five porphyritic basalts, showing strong chromium zoning with iron enrichment. Zoning within large phenocrysts shows a very slight iron increase and a decrease in $\mathrm{Cr}_{2} \mathrm{O}_{3}$. Chrome contents of the cores of some grains in sub-ophitic groundmass are $>1$ per cent $\mathrm{Cr}_{2} \mathrm{O}_{3}$, indicating that the drastic chromium depletion in groundmass rims did not occur until some of the groundmass grains had formed. Note crude correlation between bulk rock composition and pyroxene composition.

basalts (Bunch and LaBorde, 1976; Bence et al., 1976), although the overall degree of enrichment (and concomitant $\mathrm{Ca}$ decrease) is not as extreme as has been observed in other suites. The most iron-rich rim analyzed thus far in these rocks is $\mathrm{Wo}_{37} \mathrm{En}_{37} \mathrm{Fs}_{26}$.
On the basis of analyses presently available, it would appear that there is a correlation between the composition of clinopyroxene cores and the bulk composition of the rocks in which they occur. This correlation is most marked in phenocrysts in Sample 395A- 


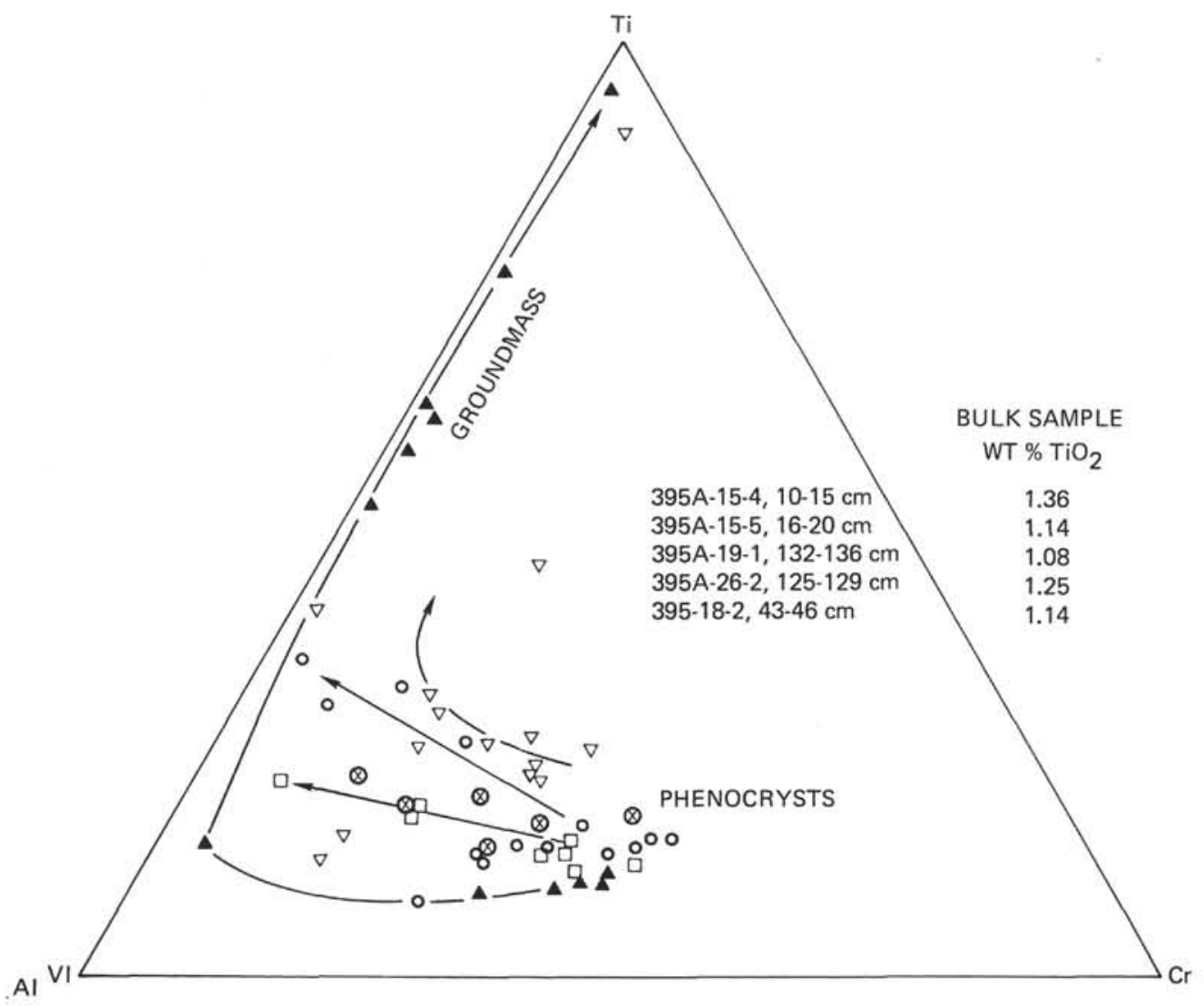

Figure 4. Microprobe analyses of clinopyroxene phenocrysts and groundmass grains in five porphyritic basalts. The trends demonstrate decreasing alumina and chromium in phenocrysts, followed by an increase in $\mathrm{TiO}_{2}$ in rims and groundmass grains. Note crude correlation between $\mathrm{TiO}_{2}$ content of bulk rock and the trend on the Ternary plot.

$15-4,10-15 \mathrm{~cm}$, from the uppermost, relatively evolved porphyritic unit $\left(\mathrm{P}_{2} \cdot 395 \mathrm{~A}\right)$. The cores of these pyroxenes have the highest $\mathrm{Fe} /(\mathrm{Fe}+\mathrm{Mg})$ and $\mathrm{TiO}_{2}$ content, as well as the lowest $\mathrm{Cr}_{2} \mathrm{O}_{3}$ content of any of the phenocrysts analyzed; this coincides with the bulk rock data, indicating higher $\mathrm{Fe} /(\mathrm{Fe}+\mathrm{Mg}), \mathrm{Cr}_{2} \mathrm{O}_{3}$, and $\mathrm{TiO}_{2}$ than the underlying units. These relationships are less clearcut for the remaining four samples, although they hold in a general sense. Additional analyses may establish more clearly whether pyroxene phenocryst compositions are sensitive to such small bulk compositional differences in their host lavas.

\section{EXPERIMENTAL DATA}

In order to place constraints on possible crystal fractionation histories of the basaltic rocks studied here, we have selected two representative samples for determination of their melting relationships and mineral compositions at one-atmosphere total pressure. In addition, we have performed controlled cooling-rate experiments in an attempt to quantify the interpretations of textures observed in the natural rocks. Although the results obtained to date are preliminary, they have been remarkably successful and allow us to draw several significant conclusions regarding the evolution and emplacement of the basalts drilled on Leg 45.

\section{Experimental Techniques}

Both the melting and cooling-rate experiments were performed using the technique, described in detail by Donaldson et al. (1975), in which samples are suspended on a $\mathrm{Pt}$ wire loop in a vertical tube furnace. Oxygen fugacity in the furnace was controlled by mixing $\mathrm{H}$ and $\mathrm{CO}_{2}$, and was measured using a modified Sato cell calibrated against the Ni-NiO buffer curve. In all the melting experiments $\mathrm{f}_{\mathrm{O}_{2}}$ was maintained at $0.5( \pm 0.1) \log$ unit below the QFM buffer curve. The temperatures of the furnace are believed to be accurate within $3^{\circ} \mathrm{C}$, and calibrations were made periodically against the melting point of Au. Approximately $100 \mathrm{mg}$ of finely ground rock powder was used for each run. For the melting runs the sample was held at temperature for 24 to 72 hours, quenched, and then removed from the furnace. The cooling-rate runs were held at $1250^{\circ} \mathrm{C}$ for 24 hours, then cooled at $1000^{\circ} \mathrm{C}$ at rates of $2^{\circ}, 10^{\circ}$, and $30^{\circ} \mathrm{C}$ per hour.

The experimental conditions just described do not duplicate the conditions on the sea floor that prevailed at eruption of the Leg 45 basalts; i.e., there was roughly $0.5 \mathrm{~kb}$ of hydrostatic pressure on the rocks at that time. Thus the conclusions we draw from these experiments are based on the assumptions that a small pressure difference and the presence of seawater in the 
TABLE 4

Microprobe Analyses of Clinopyroxenes, Leg 45

\begin{tabular}{|c|c|c|c|c|c|c|c|c|c|c|}
\hline & 1 & 2 & 3 & 4 & 5 & 6 & 7 & 8 & 9 & 10 \\
\hline $\mathrm{SiO}_{2}$ & 49.7 & 50.4 & 51.5 & 50.9 & 51.4 & 50.6 & 51.0 & 50.7 & 52.3 & 50.4 \\
\hline $\mathrm{TiO}_{2}$ & 0.82 & 0.82 & 0.65 & 0.47 & 0.78 & 0.34 & 0.34 & 1.28 & 0.66 & 0.88 \\
\hline $\mathrm{Al}_{2} \mathrm{O}_{3}$ & 4.6 & 3.8 & 1.6 & 4.2 & 3.7 & 4.1 & 3.7 & 3.3 & 1.6 & 1.5 \\
\hline $\mathrm{Cr}_{2} \mathrm{O}_{3}$ & 1.2 & 0.51 & 0.03 & 1.5 & 0.19 & 1.4 & 1.15 & 0.05 & 0.02 & 0.01 \\
\hline $\mathrm{FeO}$ & 5.7 & 6.5 & 9.4 & 4.8 & 7.6 & 4.2 & 4.3 & 10.3 & 8.9 & 15.5 \\
\hline $\mathrm{MnO}$ & 0.18 & 0.18 & 0.25 & 0.16 & 0.22 & 0.14 & 0.10 & 0.26 & 0.30 & 0.47 \\
\hline $\mathrm{MgO}$ & 15.7 & 16.3 & 17.1 & 17.0 & 18.0 & 17.3 & 17.5 & 15.3 & 17.4 & 14.0 \\
\hline $\mathrm{CaO}$ & 20.9 & 20.2 & 18.1 & 21.0 & 17.8 & 20.9 & 21.2 & 19.4 & 17.9 & 16.0 \\
\hline $\mathrm{Na}_{2} \mathrm{O}$ & 0.33 & 0.34 & 0.23 & 0.23 & 0.17 & 0.28 & 0.27 & 0.35 & 0.25 & 0.29 \\
\hline Total & 99.13 & 99.05 & 98.86 & 100.26 & 99.86 & 99.26 & 99.56 & 100.94 & 99.33 & 99.05 \\
\hline $\mathrm{Si}$ & 1.850 & 1.876 & 1.932 & 1.863 & 1.888 & 1.866 & 1.875 & 1.878 & 1.943 & 1.933 \\
\hline $\mathrm{Al}$ & 0.150 & 0.124 & 0.068 & 0.137 & 0.112 & 0.134 & 0.125 & 0.122 & 0.057 & 0.067 \\
\hline $\mathrm{Al}$ & 0.053 & 0.043 & 0.001 & 0.045 & 0.047 & 0.044 & 0.035 & 0.022 & 0.013 & 0.001 \\
\hline $\mathrm{Ti}$ & 0.023 & 0.023 & 0.018 & 0.013 & 0.022 & 0.009 & 0.009 & 0.036 & 0.018 & 0.025 \\
\hline $\mathrm{Cr}$ & 0.036 & 0.015 & 0.001 & 0.043 & 0.006 & 0.040 & 0.033 & 0.001 & 0.001 & 0.000 \\
\hline $\mathrm{Fe}$ & 0.178 & 0.201 & 0.296 & 0.146 & 0.235 & 0.130 & 0.132 & 0.319 & 0.277 & 0.497 \\
\hline $\mathrm{Mn}$ & 0.006 & 0.006 & 0.008 & 0.005 & 0.007 & 0.004 & 0.003 & 0.008 & 0.009 & 0.015 \\
\hline $\mathrm{Mg}$ & 0.868 & 0.904 & 0.954 & 0.929 & 0.987 & 0.951 & 0.959 & 0.845 & 0.964 & 0.800 \\
\hline $\mathrm{Ca}$ & 0.832 & 0.805 & 0.7 & 0.822 & 0.699 & 0.826 & 0.835 & 0.770 & 0.713 & 0.657 \\
\hline $\mathrm{Na}$ & 0.024 & 0.025 & 0.017 & 0.016 & 0.012 & 0.020 & 0.019 & 0.025 & 0.018 & 0.022 \\
\hline Total & 4.020 & 4.022 & 4.023 & 4.019 & 4.014 & 4.025 & 4.028 & 4.026 & 4.012 & 4.018 \\
\hline Wo & 44.3 & 42.1 & 36.7 & 43.3 & 36.4 & 43.3 & 43.4 & 39.8 & 36.5 & 33.6 \\
\hline En & 46.2 & 47.3 & 48.3 & 49.0 & 51.4 & 49.9 & 49.8 & 43.7 & 49.3 & 40.9 \\
\hline Fs & 9.5 & 10.5 & 15.0 & 7.7 & 12.2 & 6.8 & 6.9 & 16.5 & 14.2 & 25.4 \\
\hline
\end{tabular}

Note: (1, 2) 395 A-15-4, 10-15 cm: Core and rim of euhedral, zoned phenocryst; (3) 395 A-15-4, 10-15 cm: Rim of groundmass grain in contact with mesostasis; (4) 395A-19-1, 132-136 cm: Core of zoned phenocryst; (5) 395 A-19-1, 132-136 cm: Rim of groundmass grain; $(6,7,8) 395 \mathrm{~A}-15-4,99-107 \mathrm{~cm}$ : Core, intermediate zone, and rim of a large clinopyroxene glomerocryst intergrown with plagioclase laths; $(9,10)$ $395 \mathrm{~A}-15-5,16-20 \mathrm{~cm}$ : Core and rim of groundmass grain.

natural environment does not significantly alter the phase relations, textures, or mineral chemistry relative to the experimental system. We feel these assumptions are valid, on the basis of available high-pressure data for basaltic system (see Fujii et al., this volume). The specific $\mathrm{f}_{\mathrm{O} 2}$ values were chosen on the basis of a complication of estimated $\mathrm{T}$ versus $\mathrm{f}_{02}$ data for deepsea basalts in El Goresy, Haggerty, et al. (1976).

\section{Experimental Results}

The results of the melting experiments are presented in Figure 5, and the compositions of plagioclase and olivine are tabulated as a function of temperature in Table 5. The representative aphyric sample, 395A-9-2, $100-104 \mathrm{~cm}$, has olivine $\left(\mathrm{Fo}_{83.1-82.9}\right)$ as the liquidus phase at about $1205^{\circ} \mathrm{C}$. Between $1200^{\circ}$ and $1175^{\circ} \mathrm{C}$, olivine $\left(\mathrm{Fo}_{81.5-79.0}\right)$ is joined by plagioclase of the composition $\mathrm{An}_{66.5}$ to $\mathrm{An}_{61.5}$ (at $1175^{\circ} \mathrm{C}$ ). Clinopyroxene appears at about $1160^{\circ} \mathrm{C}$, and at that temperature the plagioclase composition varies from $\mathrm{An}_{61.6-64.7}$, whereas the olivine composition varies from $\mathrm{Fo}_{77.9-74.5}$.

A sample from the phyric unit (Sample 395A-27-2, $111-116 \mathrm{~cm})$, chosen for its relatively high $\mathrm{Mg}$ / $(\mathrm{Mg}+\mathrm{Fe})$, has plagioclase as the liquidus phase at about $1235^{\circ} \mathrm{C}\left(\mathrm{An}_{75.9-75.4}\right.$ at $\left.1225^{\circ} \mathrm{C}\right)$. Olivine begins to precipitate at about $1215^{\circ} \mathrm{C}$. At $1200^{\circ} \mathrm{C}$ the olivine composition is $\mathrm{Fo}_{86.1-84.7}$ and the plagioclase composition is $\mathrm{An}_{75.9-72.4}$ In addition, a very minor amount of spinel is present at $1200^{\circ} \mathrm{C}$. The compositions of three grains are plotted on Figure 1 and one analysis is included in Table 3. The $\mathrm{Cr} /(\mathrm{Cr}+\mathrm{Al})$ and $\mathrm{Mg} /$
$(\mathrm{Mg}+\mathrm{Fe})$ of these spinels agree very well with those occurring naturally in Sample 395A-27-2, 111-116 cm, suggesting that the experiments have successfully reproduced the oxygen fugacities that existed during crystallization of the Leg 45 basalts. That the spinels are not simply relict grains is demonstrated in a similar set of experiments on Leg 46 basalts, in which the spinel composition varied consistently over a range of temperatures (increasingly greater $\mathrm{Cr} / \mathrm{Cr}+\mathrm{Al}$ with lower temperature), indicating that the spinels do in fact readily equilibrate with a silicate melt under the conditions at which the experiments were conducted.

At $1175^{\circ} \mathrm{C}$, plagioclase $\left(\mathrm{An}_{69.8-68.4}\right)$ and olivine (Fo $\left.{ }_{83.5-84.6}\right)$ are joined by clinopyroxene, but no spinel was observed. At $1160^{\circ} \mathrm{C}$, clinopyroxene coexists with plagioclase $\left(\mathrm{An}_{72.4-65.4}\right)$, olivine $\left(\mathrm{Fo}_{79.1-76.3}\right)$, and silicate liquid, plus very small, highly reflective grains (either spinel or titanomagnetite). At $1150^{\circ} \mathrm{C}$, only a small amount liquid (10 to $20 \%$ ) coexists with olivine, plagioclase, and clinopyroxene.

\section{Cooling-Rate Experiments}

The linear cooling-rate experiments for the sample from the aphyric unit $(395 \AA-9-2,100-104 \mathrm{~cm})$ produced textures ranging from spherulitic $\left(30^{\circ} / \mathrm{hr}\right.$ cooling rate) to slightly porphyritic $\left(2^{\circ} / \mathrm{hr}\right.$ cooling rate). At the $30 \%$ hr cooling rate, spherules of olivine dendrites are set in residual glass, which makes up the bulk of the charge. In the $10 \% / \mathrm{hr}$ run, olivine and plagioclase occur as oriented arrays of acicular crystals. In parts of the charge, olivine occurs as skeletal crystals which 

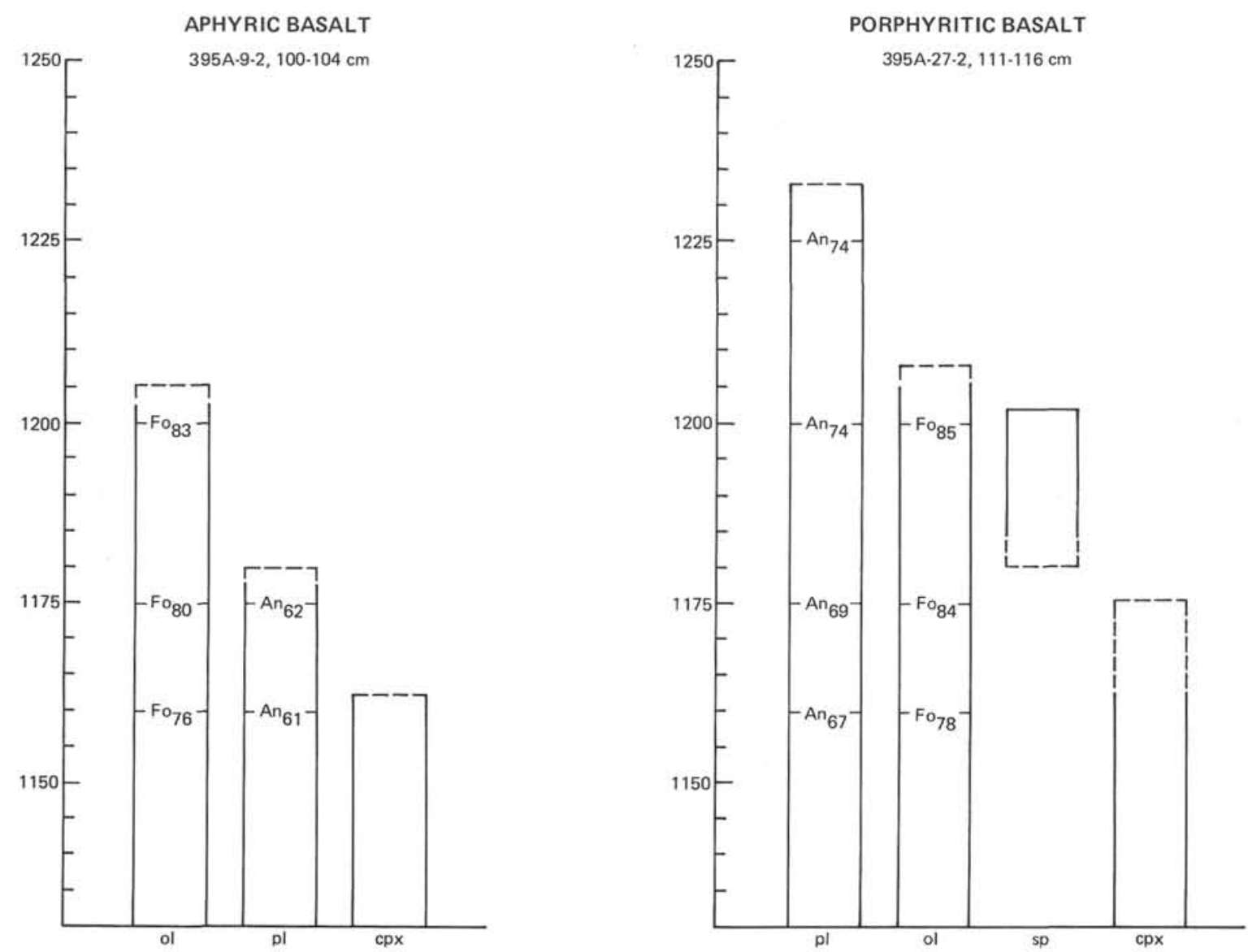

Figure 5. Graphic presentation of one-atmosphere melting experiment, results of two basalts (aphyric and phyric). Hole $395 \mathrm{~A}$.

TABLE 5

Compositions of Olivine and Plagioclase From Experimental Runs

\begin{tabular}{|c|c|c|c|c|c|c|c|c|}
\hline \multirow{3}{*}{$\begin{array}{c}\text { Temperature } \\
\left({ }^{\circ} \mathrm{C}\right)\end{array}$} & \multicolumn{4}{|c|}{ Sample $395 \mathrm{~A}-27-1,111-116 \mathrm{~cm}$} & \multicolumn{4}{|c|}{ Sample 395A-9-2, 100-104 cm } \\
\hline & \multicolumn{2}{|c|}{$\begin{array}{c}\text { Fo Content of } \\
\text { Olivine }\end{array}$} & \multicolumn{2}{|c|}{$\begin{array}{c}\text { An Content of } \\
\text { Plagioclase }\end{array}$} & \multicolumn{2}{|c|}{$\begin{array}{l}\text { Fo Content of } \\
\text { Olivine }\end{array}$} & \multicolumn{2}{|c|}{$\begin{array}{c}\begin{array}{c}\text { An Content of } \\
\text { Plagioclase }\end{array} \\
\end{array}$} \\
\hline & Range & Mean & Range & Mean & Range & Mean & Range & Mean \\
\hline 1225 & & & $74.8-72.1$ & 73.7 (4) & & & & \\
\hline 1200 & $86.1-84.7$ & $85.1(10)$ & $75.4-72.4$ & $74.2(4)$ & $83.2-82.9$ & $83.1(7)$ & & \\
\hline 1175 & $84.6-83.9$ & $84.2(5)$ & $69.8-68.4$ & $69.3(3)$ & $81.5-79.0$ & 80.0 (5) & $63.4-61.5$ & $62.6(4)$ \\
\hline 1160 & $29.1-76.3$ & 77.4 (5) & $71.0-65.4$ & $68.2(2)$ & $77.9-74.5$ & $76.3(8)$ & $63.2-58.5$ & $61.5(4)$ \\
\hline
\end{tabular}

clearly nucleated early in the crystallization history, whereas in others olivine appears to be interstitial to plagioclase laths. The charge also contains small tabular grains of titanomagnetite and euhedral grains of clinopyroxene (?). A cooling rate of $2^{\circ} / \mathrm{hr}$ produced large skeletal olivines which are set in a fan-spherulitic groundmass of plagioclase, olivine, clinopyroxene, and titanomagnetite. A typical example of the large olivine grains is shown in Plate 1, Figure 5. Olivine also occurs in chain-like morphologies similar to those shown in fig. 2 of Donaldson (1976).

Textures produced by controlled cooling rates of samples from the phyric unit (395A-27-2, 111-116 cm) differ markedly from those of the aphyric unit. A $30^{\circ}$ \% hr cooling rate produced radiating plagioclase needles in a very fine grained spherulitic matrix, whereas a $10^{\circ} / \mathrm{hr}$ cooling rate produced skeletal plagioclase laths in a matrix of plagioclase olivine and clinopyroxene. At a $2^{\circ} / \mathrm{hr}$ cooling rate, plagioclase laths and subhedral olivine are set in a matrix of olivine, plagioclase, and spherulitic clinopyroxene.

\section{Discussion of Cooling-Rate Experiments}

The results of the controlled cooling-rate runs place some constraints on the crystallization history of the aphyric unit. In general, olivine morphology gives some indication as to the relative deqree of undercooling at the time of crystallization (Donaldson, 1976). 
These experiments confirm this, in that different cooling rates produce different degrees of undercooling, which in turn can be correlated systematically with olivine morphology. Olivine morphologies in various parts of the aphyric unit can be used then, to make some broad inferences about cooling rates. Specifically, the olivine morphology of the $2 \% / \mathrm{hr}$ run is very similar to the larger crystals in the glassy rinds and in the interior parts of pillows in the aphyric unit. The range of morphologies within the aphyric unit, however, covers the same range of morphologies seen in going from the $2 \% / \mathrm{hr}$ run to the $30^{\circ} / \mathrm{hr}$ run. The similarity between the late dendritic crystals in the aphyric unit pillow rinds and those grown in the $30 \% / \mathrm{hr}$ run is remarkable, and suggests that undercooling similar to that established in the $30^{\circ} / \mathrm{hr}$ cooling run occurred at the later stages of crystallization in the pillow rinds. That there are also early, more equant olivine crystals in the pillow rinds suggests that crystallization of the pillows took place at increasingly greater degrees of undercooling. A similar conclusion was arrived at by Kirkpatrick (1976) on a calculational basis, although it is not clear whether the increasing undercooling stems from an externally imposed thermal regime or whether it is inherent in the crystallization behavior of the melt itself. The progressive change in texture from the pillow rim inward does suggest, however, the general importance of the imposed thermal regime, and that the effective average relative undercooling was substantially greater at the pillow rind than in the pillow interior.

On the basis of these experiments, cooling rates ranging from $2^{\circ}$ to $30^{\circ} / \mathrm{hr}$ can maintain the respective undercoolings necessary to produce the range of textures observed in the aphyric unit. It is important to note, however, that the experiments on the aphyric unit sample (395A-9-2, 100-104 cm) were conducted under conditions that involved considerable superheat before beginning the controlled drop, and this may affect the resulting textures. Additional experiments are planned which will involve minimal superheat, but at the present time caution is needed in attempting to make direct comparisons between the cooling rates of our experiments and those which may have produced the textures observed in natural basalt samples.

The cooling-rate experiments for the phyric basalt are less easily interpreted, because it is clear that the natural magmas were charged with crystals at the time of eruption, whereas the experimental charges were crystallized continuously from an entirely melted sample. Thus the effect of having a large number of crystals present before onset of relatively rapid cooling has not been realistically modeled in these experiments.

\section{SUMMARY AND CONCLUSIONS}

Two distinct textural-chemical types of basalts are present in Holes 395 and 395A. Aphyric basalts are predominantly relatively evolved compositions that occur almost entirely in pillowed units $\left(\mathrm{A}_{2}, \mathrm{~A}_{3}\right.$, and $A_{4}$ ). Unit $A_{2}$ is the least chemically evolved (about
$10 \%$ normative olivine) and has olivine alone on the liquidus. This conclusion is derived from the presence of olivine microphenocrysts in very rapidly chilled samples and from one-atmosphere melting experiments that indicate liquidus olivine at about $1200^{\circ} \mathrm{C}$ followed by plagioclase at about $1175^{\circ} \mathrm{C}$. The compositions of olivine and plagioclase in the experimental charges agree, to within one per cent, with those determined in the rocks. Aphyric units $\mathrm{A}_{4}$ and $\mathrm{A}_{3}$ are progressively more evolved than $A_{2}$, and have microphenocrysts of both olivine and plagioclase, suggesting multiple saturation. Those compositions are quite similar, with the exception of xenocrysts of olivine and plagioclase, in Unit $A_{3}$, that are more forsteritic and anorthitic, respectively, than the microphenocrysts.

The porphyritic basalts are far more complex. Integration of bulk chemical data from Rhodes et al. (this volume) with the petrographic, phase chemical, and experimental studies in this paper suggests that many of the olivine and plagioclase phenocrysts present in these did not crystallize from melts with the composition of the rocks, but from a more primitive basalt. Specifically, many of these phenocrysts are either more forsteritic or anorthitic than the experimentally determined olivine and plagioclase in a relatively magnesian porphyritic basalt. In addition, the various types of zoning patterns (including reversed) recognized in plagioclase phenocrysts within individual samples indicate that a mixed population is present. In all the porphyritic basalts from which we have microprobe analyses of olivine, several of the phenocrysts are more magnesian than the composition predicted by the work of Roeder and Emslie (1970). Spinel and clinopyroxene follow plagioclase and olivine in the crystallization sequence of the porphyritic basalts. Spinel crystallization is terminated with the incoming of clinopyroxene. As the spinel and clinopyroxene compositions appear to correlate with the bulk chemistry of the samples in which they occur, they are probably not exotic to these rocks.

Presently we are examining the possibility that mixing of evolved magmas with more magnesian primitive magmas can account for the major and minor element characteristics of these lavas, as well as their disequilibrium mineralogy. Preliminary data on basalts from Leg 46 indicate many of the same mineral chemistry anomalies and bulk chemical characteristics.

\section{REFERENCES}

Bence, A. E., Papike, J. J., and Ayuso, R. A., 1976. Petrology of submarine basalts from the central Caribbean: DSDP Leg 15: J. Geophys. Res., v. 80, p. 4775.

Bryan, W. B., 1972. Morphology of quench crystals in submarine basalts: J. Geophys. Res., v. 77, p. 5812-5819.

Bunch, T. E. and LaBorde, R., 1976. Mineralogy and compositions of selected basalts from DSDP Leg 34. In Yeats, R. S., Hart, S. R., et al., Initial Reports of the Deep Sea Drilling Project, v. 34: Washington (U. S. Government Printing Office), p. 263-275.

Dick, H. S. B., in press. The geochemistry of chrome spinel in FAMOUS basalts and a model for magma genesis at an ocean ridge: Contrib. Mineral. Petrol. 
Donaldson, C. H., Usselman, T. M., Williams, R. J., and Lofgren, G. E., 1975. Experimental modeling of the cooling history of Apollo 12 olivine basalts: Sixth Lunar Sci. Conf. Proc., p. 843-869.

Donaldson, C. H., 1976. An experimental investigation of olivine morphology: Contrib. Mineral. Petrol., v. 57, p. 187-213.

El Goresy, A., Haggerty, S. E., Hubner, J. S., Lindsley, D. H., and Rumble, D., III, 1976. Oxide Minerals. v. 3 of Short Course Notes, Mineral. Soc. Am., p. Hg 163.
Frey, F. A., Bryan, W. B., and Thompson, G., 1974. Atlantic Ocean floor: geochemistry and petrology of basalts from Legs 2 and 3 of the Deep-Sea Drilling Project: J. Geophys. Res., v. 79, p. 5507-5527.

Roeder, P. L. and Emslie, R. F., 1970. Olivine-liquid equilibrium: Contrib. Mineral Petrol., v. 29, p. 275-289.

Sigurdsson, H. and Schilling, J. G., 1976. Spinels in MidAtlantic Ridge basalts: chemistry and occurrence: Earth Planet. Sci. Lett, v. 29, p. 7-20.. 



\section{PLATE 1}

Figure 1 Sample $395-11-1,136-138 \mathrm{~cm}$ : Olivine microphenocrysts in the rapidly quenched groundmass at pillow margin in Unit A (width across photo $=1.25 \mathrm{~mm}$ )

Figure 2 Sample 395-15-2, 68-72cm: (same scale, Unit A). A more slowly cooled variant from the same unit, containing equant microphenocrysts in a fitted groundmass of poorly developed fan spherulites of plagioclase needles, with associated skeletal groundmass olivine and very fine grained interstitial phumose pyroxene.

Figure 3 Sample 395-16-3, 3-8cm: Another still more slowly cooled variant from the same unit (note change of scale-width of photograph $=2.5$ $\mathrm{mm})$. Plagioclase needles are pyroxene and interstitial skeletal clinopyroxene are more coarse-grained. Fan spherulites generally radiate from olivine microphenocrysts.

Figure 4 Sample 395-11-2, 100-105cm: (same scale as c). Most coarse-grained textural variant. The texture is intergranular-intersertal, and at these slower cooling rates the mineralogy is dominated by skeletal plagioclase laths.

Figure 5 Sample 395A-9-2, 100-104cm: Product of linear cooling rate of $2^{\circ} \mathrm{C} / \mathrm{hr}$. Skeletal olivine microphenocrysts in a fine-grained groundmass similar to that shown in Figure 1.

Figure 6 Sample 395A-46-1, 61-64cm: Typical intersertal texture of aphyric basalts in Unit $A_{3}$ (width across photograph $=2.5 \mathrm{~mm}$ ).

Figure 7 Sample 395A-56-3, 62-65cm: (same scale as 6) Rounded plagioclase xenocryst in glassy pillow rind. Note embayed outline, suggestive of resorption.

Figure $8 \quad$ Detail of the margin of the xenocryst (left) against glass. The spherulitic overgrowth on the xenocryst and single microlite of plagioclase adjacent to xenocryst appear as a black band. Note also olivine microphenocrysts in glass (width of photograph $=.1 .25 \mathrm{~mm}$ ). 
PLATE 1
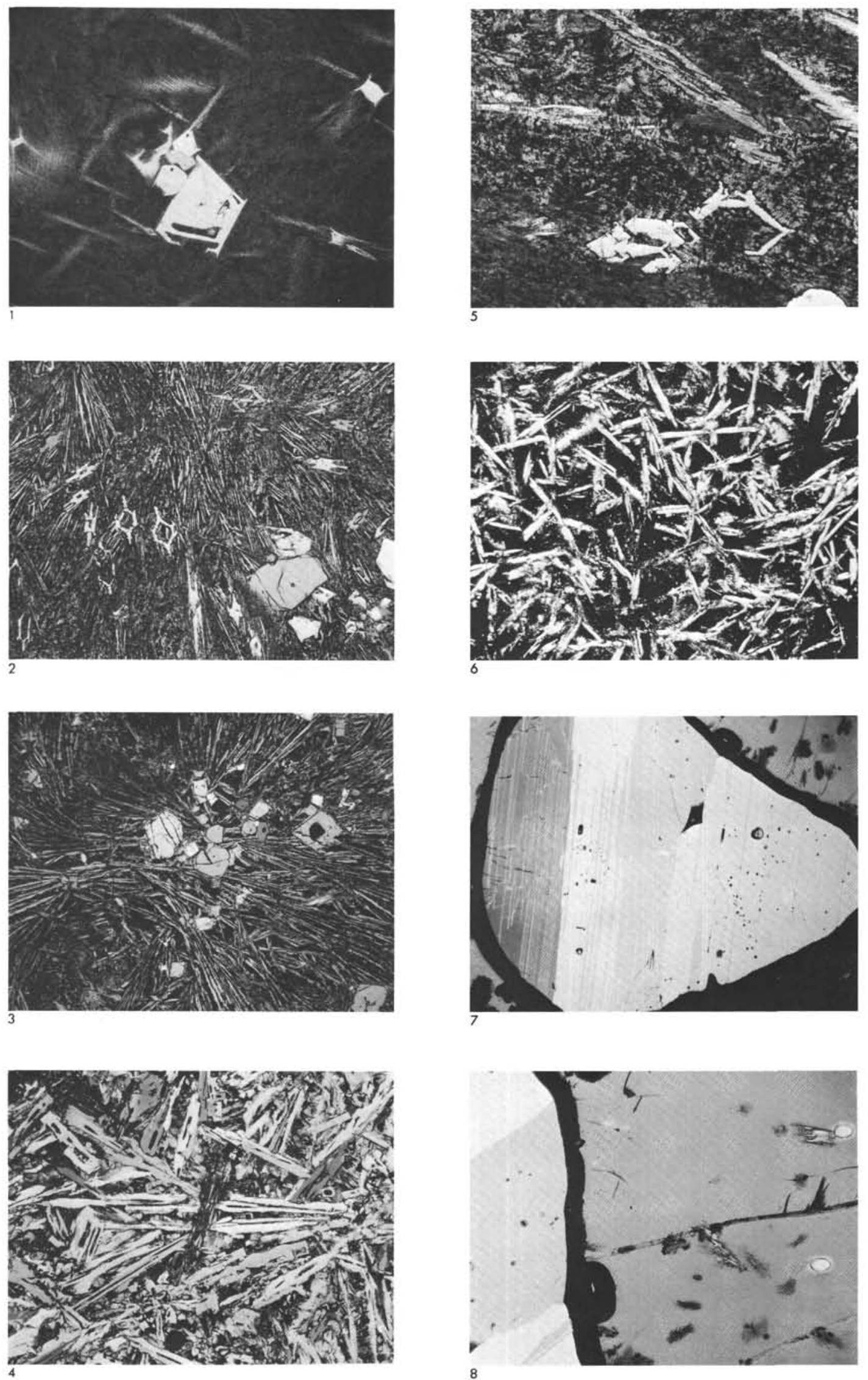


\section{PLATE 2}

Figure 1 Sample 395A-15-4, 10-15cm: Typical porphyritic basalt with subophitic groundmass in Unit $\mathrm{P}_{2}$. Note large plagioclase glomerocrysts, consisting of large weakly zoned cores and abrupt rims (width of photograph $=1.1 \mathrm{~cm}$ ).

Figure 2 Sample 395-18-2, 43-46cm: Plagioclase phenocryst exhibiting complex oscillatory zoning and containing numerous melt inclusions in the core. Most phenocrysts in these rocks do not exhibit this type of zoning pattern (width of photograph $=3.5 \mathrm{~mm}$ ).

Figure 3 Sample 395A-38-1, 116-122cm: An example of the least common distinctive zoning-pattern type in the porphyritic basalts. The core is $\mathrm{An}_{59-60}$ and the rim (darker) is more calcic at $\mathrm{An}_{73-71}$. Note vermicular zone in between core and rim, indicative of resorption (width of photograph $=2.5 \mathrm{~mm}$ ).

Figure 4 Sample 395A-27-2, 111-116cm: A complex olivine-plagioclase-spinel glomerocrystic aggregate is illustrated. A single large olivine with a highly irregular outline and numerous melt inclusions is intergrown with plagioclase phenocrysts that exhibit variable zoning patterns (width of photograph $=3.5 \mathrm{~mm}$ ).

Figure 5 Sample 395A-27-2, 111-116cm: A large euhedral olivine phenocryst contains melt inclusions and two anhedral plagioclase grains (width of photograph $=2.5 \mathrm{~mm}$ ).

Figure 6 Sample 395A-15-4, 10-15cm: Typical zoning pattern in clinopyroxene phenocryst (width of photograph $=1.5 \mathrm{~mm}$ ). 
PLATE 2
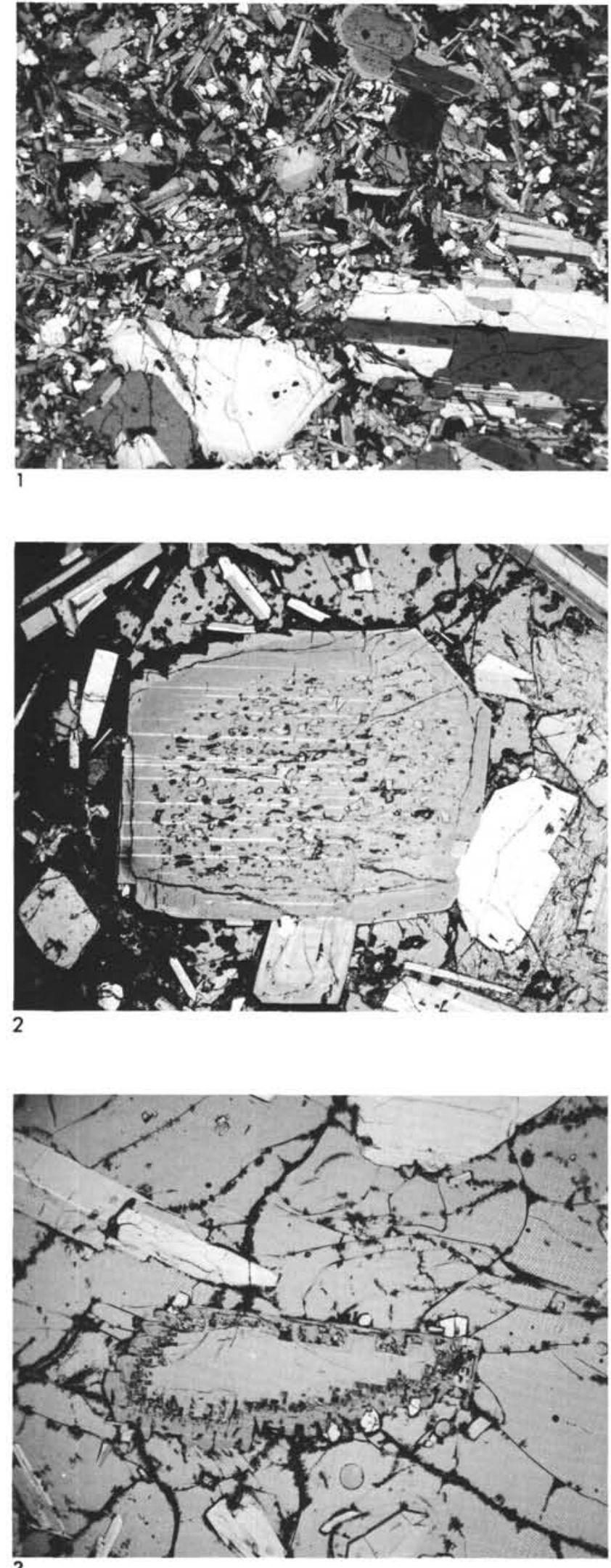
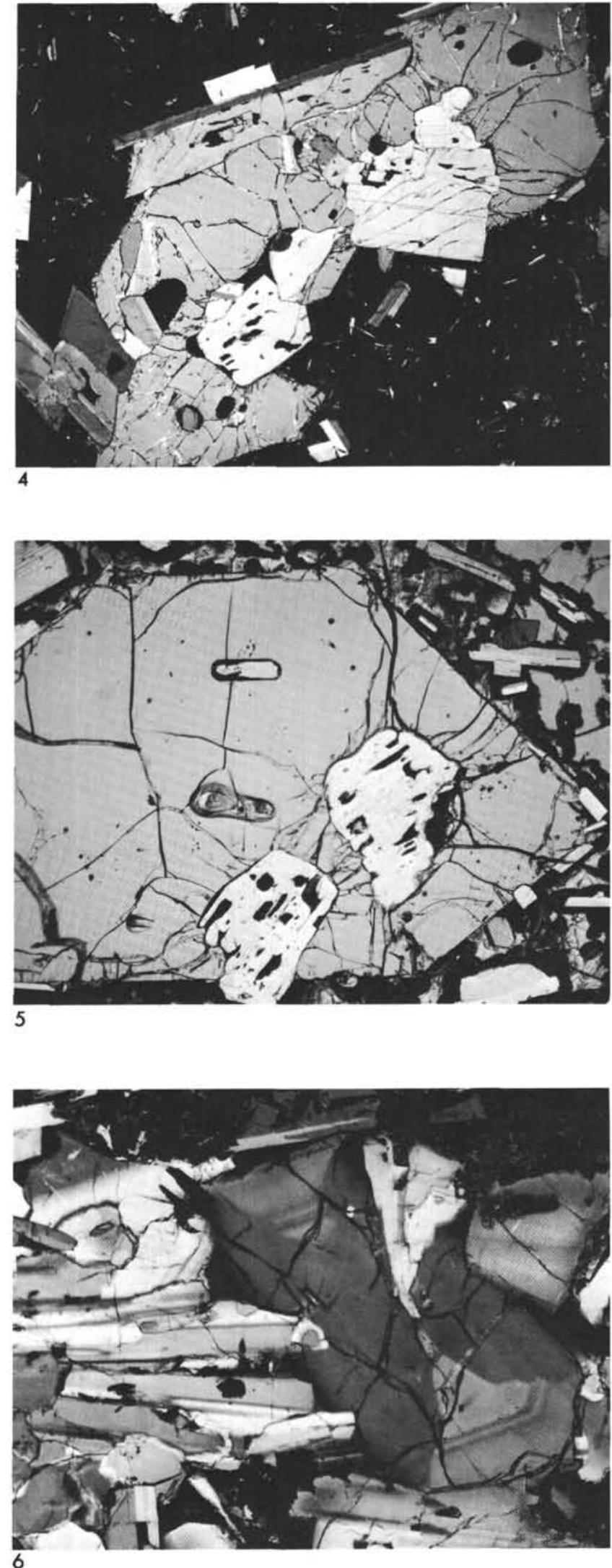